Received $\quad 01.09 .2018$

Reviewed $\quad 03.10 .2018$

Accepted 23.10.2018

A - study design

B - data collection

C - statistical analysis

D - data interpretation

E - manuscript preparation

$\mathbf{F}$ - literature search

\section{Natural and anthropogenic conditions of water level fluctuations in lakes - Lake Powidzkie case study (Central-Western Poland)}

\author{
Bogumil M. NOWAK ${ }^{1) A B C D E F} \bowtie$, Mariusz PTAK ${ }^{2) ~ C D E F ~}$
}

1) orcid.org/0000-0002-6963-770X; Institute of Meteorology and Water Management - National Research Institute, Podleśna 61, 01-673 Warszawa, Poland; e-mail: rugosa@op.pl

2) orcid.org/0000-0003-1225-1686; Adam Mickiewicz University, Faculty of Geographical and Geological Sciences, Poznań, Poland; e-mail: marp114@wp.pl

For citation: Nowak B.M., Ptak M. 2019. Natural and anthropogenic conditions of water level fluctuations in lakes - Lake Powidzkie case study (Central-Western Poland). Journal of Water and Land Development. No. 40 (I-III) p. 13-25. DOI: 10.2478/jwld-2019-0002.

\begin{abstract}
The article presents the analysis of water level fluctuations in Lake Powidzkie in the years 1961-2015. The study shows a considerable decrease in mean water levels in the aforementioned multiannual period, averaging $9 \mathrm{~cm} \cdot \mathrm{decade}^{-1}$. Such a situation is caused by natural as well as anthropogenic factors, co-determining water relations in the study area. The natural factors include the amount and distribution of precipitation, increase in air temperature and evaporation size, unfavourable relations between the lake and catchment or hydrogeological conditions. Anthropogenic factors particularly include long-term transformations of the natural environment in the region, currently associated with meliorations accompanying the nearby opencast brown coal mines and exploitation of groundwaters for municipal purposes. Water shortages occurring during dry periods were shown not to be compensated in the study area in humid years. This is particularly related to the regional lowering of the aquifer remaining in close relations with Lake Powidzkie. Counteracting the unfavourable hydrological situation is done through hydrotechnical infrastructure which partially limits water outflow from the lake through damming.
\end{abstract}

Key words: climatic conditions, environmental anthropopressure, Lake Powidzkie, water level changes, water resources

\section{INTRODUCTION}

Water level fluctuations in lakes and rivers result from processes related to water circulation. The variability of water levels is of various character, referring to the scale of the fluctuations and their time of occurrence [MINEA et al. 2016; WRZESIŃSKI, PTAK 2016; 2017]. Situations with recorded specified tendencies or their lack are determined by overlapping natural and anthropological factors [PTAK et al. 2013]. The determination of which of the groups of factors plays the dominant role in changes in the water balance, and consequently in water level fluctuations, is difficult, or sometimes even impossible [CHOIŃSKI et al. 2016; JAŃCZAK, CHOIŃSKI 1988]. In Poland, in terms of the conditions of water circulation, central Poland is a specific region. It shows the lowest precipitation averaging below
$550 \mathrm{~mm} \cdot \mathrm{year}^{-1}$ [WoŚ 2010], and relatively high air temperatures, resulting in high losses related to evaporation. The hydrological-climatic specificity of the area is further exacerbated by intensive transformations of the environment resulting from human activity, lasting for at least several centuries. The first phase of the activities was related to large-scale melioration works in the $18^{\text {th }}$ and $19^{\text {th }}$ century [KANIECKI 1997; 2007], continued until the middle of the previous century. The recent decades brought transformations of water relations related to the extraction of brown coal. The aforementioned factors affected the water relations of the study area negatively - as reflected among others in a decrease in lake water levels.

The objective of the paper is the determination of the causes of a decrease in the water level in Lake Powidzkie. The objective was implemented based on an interdiscipli- 
nary analysis referring both to the environmental (natural) factors, and those related to human activity.

\section{STUDY AREA}

In terms of the regional division into physical-geographic units by KONDRACKI [2009], the study area is located within the Gnieźnieńskie Lakeland, and partially on the Wrzesińska Plain in central Poland (Fig. 1). The lake itself, with a surface area of $1078 \mathrm{ha}$, is the largest lake in Wielkopolska and one of the deepest in the country $-47 \mathrm{~m}$ (own research). In hydrographic terms, the entire study area belongs to the catchment of the Warta River, and specifically its right tributary Meszna, taking its origin on the southern edge of the discussed lake. The boundaries of the catchment of Lake Powidzkie are determined by the terminal moraine hills dominating in the landscape, and positive landforms of fluvioglacial accumulation related to the Poznań phase of the last glaciation, constituting a $3^{\text {rd }}$ order watershed between the catchments of the Meszna River discharging its waters southwards, the Noteć Zachodnia River and the Ostrowo-Gopło Channel, constituting tributaries of the Noteć River and flowing northwards, and the Struga Biskupia River, draining areas east of the lake and feeding the Ślesiński Channel. The lake is fed by several small streams of periodical character with mean discharge not exceeding several tens of $\mathrm{dm}^{3}$ per second [NOWAK 2018; NOWAK, MIELCAREK 2016]. As pointed out earlier, the area stands out on the background of the climatic conditions of Poland due to low precipitation and high poten-

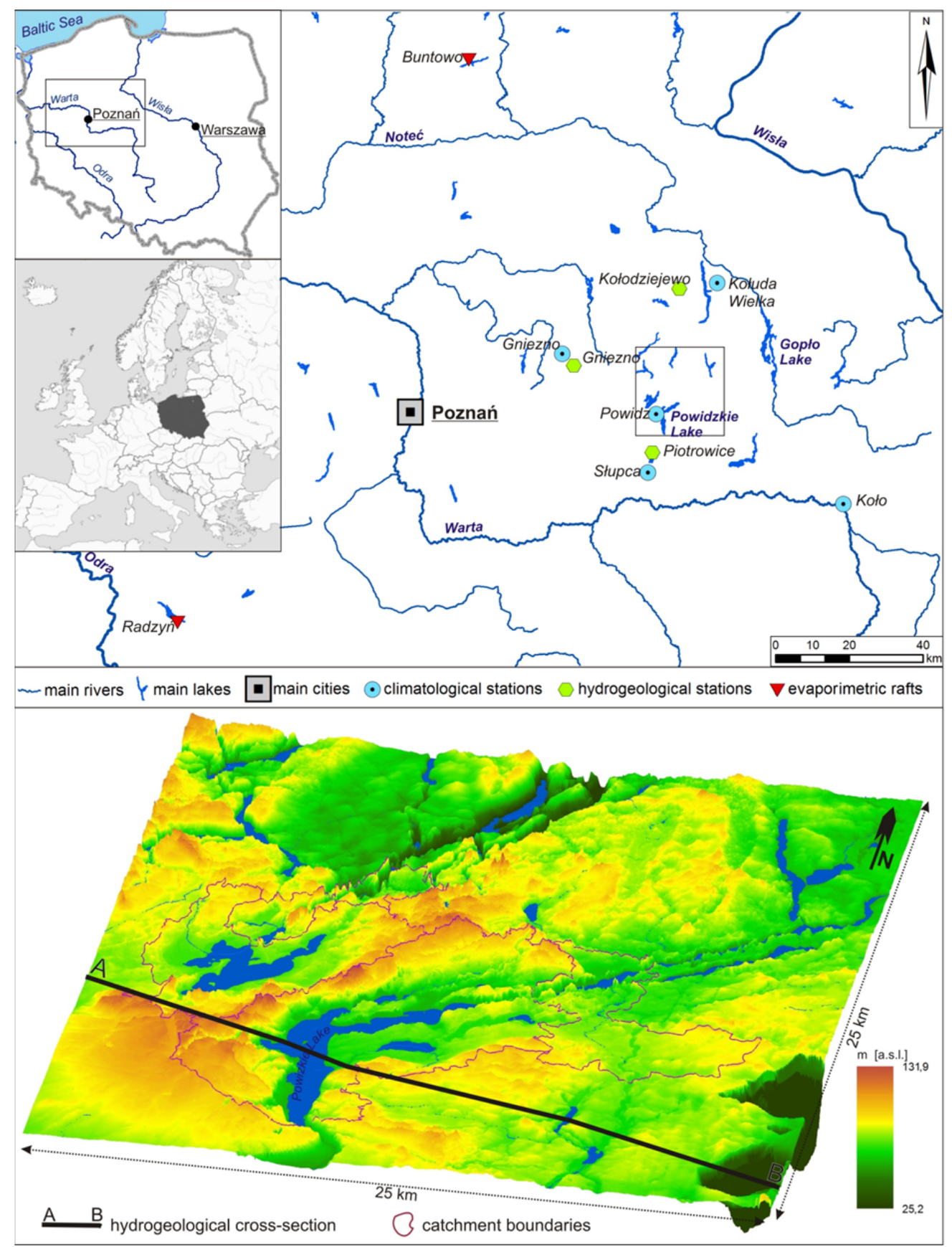

Fig. 1. Location of Lake Powidzkie; source: NowAK [2018], modified 
tial evaporation, in recent years exceeding $800 \mathrm{~mm} \cdot \mathrm{year}^{-1}$. The lake catchment is of agricultural-forest character, whereas considerable growth of land for holiday building development in the area over the last 20 years should be emphasised. Opencast lignite mines are located at a distance of approximately a dozen kilometres east of the lake, causing the depression cone covering the eastern parts of the lake's catchment.

\section{MATERIALS AND METHODS}

The determination of the environmental parameters of the analysed area was based on data concerning among others meteorological and hydrogeological elements. The largest amount of information was obtained from the Institute of Meteorology and Water Management - National Research Institute (Instytut Meteorologii i Gospodarki Wodnej - Państwowy Instytut Badawczy - IMGW). The data covered: water gauge readings from lakes and rivers located in the area of the Gnieźnieńskie Lakeland, and meteorological data from the nearest synoptic, climatological, and precipitation stations. Information on the climate and hydrology of the analysed area was supplemented with data from the measurement-observation network of Brown Coal Mine Konin, measurements from the Military Airport Meteorological Station in Powidz, and climatological station Giewartów-Holendry, belonging to the monitoring networks of the Institute of Soil Science and Plant Cultivation - National Research Institute (Insytut Upraw i Nawożenia Gleb - Państwowy Instytut Badawczy - IUNG). The information covered observation series reaching back for up to several decades.

Information on groundwater level fluctuations was particularly obtained from the monitoring network of the Polish Geological Institute - National Research Institute (Polski Instytut Geologiczny - Państwowy Instytut Badawczy - PIG), Brown Coal Mine Konin (Kopalnia Węgla Brunatnego Konin - KWB Konin), and from the State Forests (Lasy Państwowe - LP). The description of groundwater levels also applied measurements performed on piezometers located at communal waste dumps and wastewater treatment plants, as well as at gas stations located in the study area. The local commune offices and entities administering communal groundwater intakes provided information on monthly water intake and on measurements of groundwater levels taken at rest for the exploited wells. Additional information on groundwater levels was obtained from the monitoring network covering piezometers and limnometric wells established in the scope of a research grant of National Science Centre (Narodowe Centrum Nauki) Poland. Moreover, observations of surface water and groundwater levels were conducted in selected mining wells and special control sites.

The geological characteristics were determined based on data from geological corings obtained from the Central Bank of Hydrogeological Data - HYDRO and from the Department Archives of Brown Coal Mine Konin.

Climatic water balance $(C B W)$, calculated as the difference between precipitation $(P)$ and evaporation $(E)$, for the purposes of this paper was performed in a monthly cy- cle for the years 1961-2015, expressed in units of height of water column $(\mathrm{mm})$ per mean surface area of the lake in a given month. Precipitation values were adopted based on meteorological data obtained from precipitation stations of IMGW located in the study area, whereas the calculations considered adjusted values. The approach seems to be justified, because each measurement instrument involves a measurement error determined by many factors, specified in detail by BYCZKOWSKI [1999]. They are among others: water losses to wetting the container and the internal part of the rain gauge receiver; precipitation water losses to evaporation; missing the rain gauge by part of rain drops or snowflakes resulting from wind field disturbance caused by the rain gauge (so-called Jevons's effect); blowing out or in of snow to the rain gauge cylinder, or splashing of raindrops on the rain gauge ring. The application of relevant formulas permits minimising the errors and making the measured values approximate to the actual ones. The problem has been discussed by many authors [KĘDZIORA 2008a, b; 2011; MIKULSKI 2000]. For Polish conditions, it was presented the most comprehensibly in studies by employees of the Hydrological Station in Radzyń who repeatedly compared different methods of adjustment of precipitation measured at a height of $1 \mathrm{~m}$ in a Hellmann's rain gauge, constituting the basic tool of measurement of precipitation amount in the observation network of IMGW and many other institutions. Their papers [RÖSLER, CHMAL 2010; RÖSLER et al. 2007] allow for tracing the amount of adjustment applied by other authors [CHOMICZ 1976; KĘDZIORA 2008a; KOWALCZYK, UJDA 1987; MolgA 1951] for different years and for different areas of Poland. The values vary from 18 to $55 \%$ in the winter half-year, and from 8 to $22 \%$ in the summer half-year. They are evidently very variable. Considering the relative proximity of the location of the study area to the location of the Hydrological Station in Radzyń, results of works conducted there were employed. The following corrections were applied in calculations of adjusted precipitation: $20 \%$ for winter months (Dec-Feb), 15\% for spring (Mar-May) and autumn months, and 10\% for summer months (Jun-Aug). The distribution of precipitation within the lake was calculated for fields with sides $100 \times 100 \mathrm{~m}$, interpolating the adjusted results from precipitation stations located nearest to the lake.

Based on data obtained from climatological stations located nearest to the study area, values of evaporation from the water surface were calculated by means of the Iwanow [KĘDZIORA 2008b] and JAWORSKI formulas [2004] for the winter half-year. The formulas are as follows:

- Iwanow

$$
E=0.0018(t+25)^{2} \cdot(100-h)
$$

Where: $E=$ monthly evaporation (mm), $t=$ mean monthly air temperature in a meteorological cage at a height of $2 \mathrm{~m}$ above ground surface $\left({ }^{\circ} \mathrm{C}\right), h=$ mean monthly relative air humidity $(\%)$;

- Jaworski

$$
E_{0}=0.225\left(u_{2}+1\right)^{0.5} \cdot\left(e_{0 j}-e\right)
$$


Where: $E_{0}=$ daily evaporation $(\mathrm{mm}), u_{2}=$ mean daily wind speed at a height of $2 \mathrm{~m}$ above ground surface $\left(\mathrm{m} \cdot \mathrm{s}^{-1}\right), e_{0 j}=$ mean monthly value of pressure of saturated water vapour at lake water surface temperature $(\mathrm{hPa}), e=$ mean monthly value of water vapour pressure in air in a meteorological cage at a height of $2 \mathrm{~m}$ above ground surface $(\mathrm{hPa})$.

Based on studies by KęDZIORA [2008a, b; 2011] and RÖSLER et al. [2013], the Iwanow formula was selected for periods with ice cover, and the Jaworski formula for winter months with no occurrence of ice on lakes. The adopted rules required the determination of the duration of ice cover for the studied lake. It was done based on the daily log of water gauge observations run for Lake Powidzkie, and field surveys. Calculations for the summer half-year also employed the Jaworski formula and data on actual evaporation, measured on evapometric rafts in Radzyń on the Lake Sławskie and in Buntowo on the Lake Sławianowskie, belonging to the measurement network of IMGW. The measured values for the selected sites were interpolated for the area of Poland and transposed to Lake Powidzkie. For the years in which constant measurements on evaporimetric rafts were not performed, i.e. until 1976, the Jaworski formula was used. According to research conducted at the IMGW, it showed the lowest error in comparison to actual measurements [RÖSLER et al. 2013]. In the case of calculations performed by means of Jaworski's [JAWORSKI 2004] and Iwanow's method [KĘDZIORA 2008b], meteorological data obtained from the nearest climatological and synoptic stations of IMGW in Koło, Słupca, and Gniezno were applied.

\section{RESULTS AND DISCUSSION}

\section{CLIMATIC CONDITIONS}

Precipitation and air temperature, relative air temperature, relative air humidity, and wind, determining the amount of evaporation, are of key importance for the scale and value of water level fluctuations in lakes.
Mean precipitation total in the analysed multiannual period amounted to $538 \mathrm{~mm}$, showing a minimum decreasing tendency (Fig. 2). In particular years, the values were very variable, as expressed in the alternating sequences of dry, wet, and normal years. According to the division by KACZOROWSKA [1962], analysing the hydrological situation based on the frequency of occurrence of wet and dry years in comparison to the normal year, dry years in the analysed area occurred nine times (75-89\% norm), and very dry five times $(50-74 \%$ norm $)$. Wet years occurred nine times (111-124\%) and very wet five times (>125\%). Maximum deviations of annual precipitation values in a wet year in comparison to a normal year from the multiannual period amount to $140-160 \%$, and in a dry year to $50-60 \%$. In the case of precipitation, three evident dry periods are observed (1982-1984, 1989-1992 and 20032005) - Figure 2.

Mean air temperature on the nearest gauging station in Shupca (located at a distance of approximately $5 \mathrm{~km}$ from the analysed lake) in the years 1961-2015 amounted to $8.3^{\circ} \mathrm{C}$. In the period, it was characterised by a considerable increasing tendency averaging $0.3^{\circ} \mathrm{C} \cdot \mathrm{decade}^{-1}$ (Fig. 3).

In the case of relative air temperature, an unfavourable tendency is observed for the area, reflected in a decrease in the value of the parameter throughout the analysed period [KĘDZIORA 2008b; NOWAK 2018]. An evident increase in air temperature and decrease in relative air humidity contributed to intensified evaporation. The graph presenting changes in the value of potential evaporation in the area of the Lake Powidzkie (Fig. 4) shows the occurrence of alternating periods with decreased and increased evaporation over the last 55 years, whereas in the 1960's and 1970's, the parameter was at a level of $600 \mathrm{~mm} \cdot \mathrm{year}^{-1}$, as also confirmed by available research [JURAK 1986; NOWAK 2018]. The values began increasing after 1990, and particularly over the last 10 years, as also confirmed by research by KĘDZIORA [2008b]. In 2015, the record value of evaporation substantially exceeded $800 \mathrm{~mm} \cdot \mathrm{year}^{-1}$.

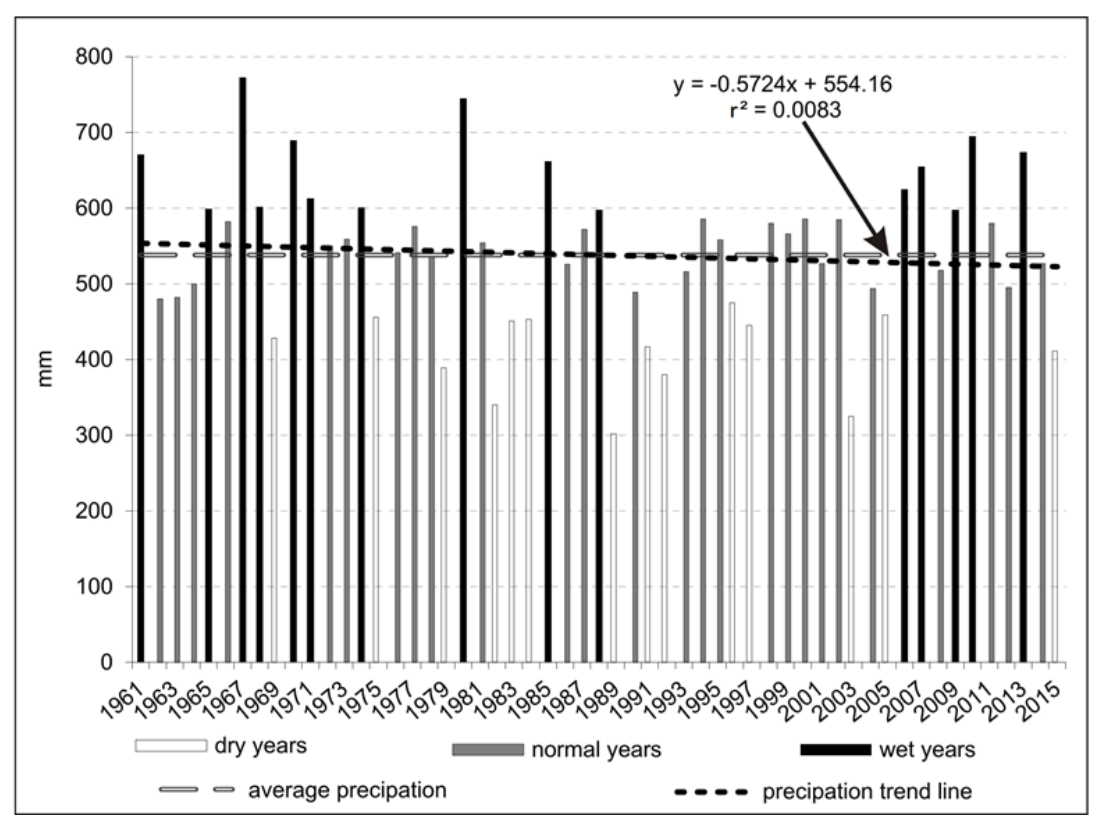

Fig. 2. Annual precipitation totals measured on the precipitation station in Powidz in the years 1961-2015; source own elaboration based on IMGW data 


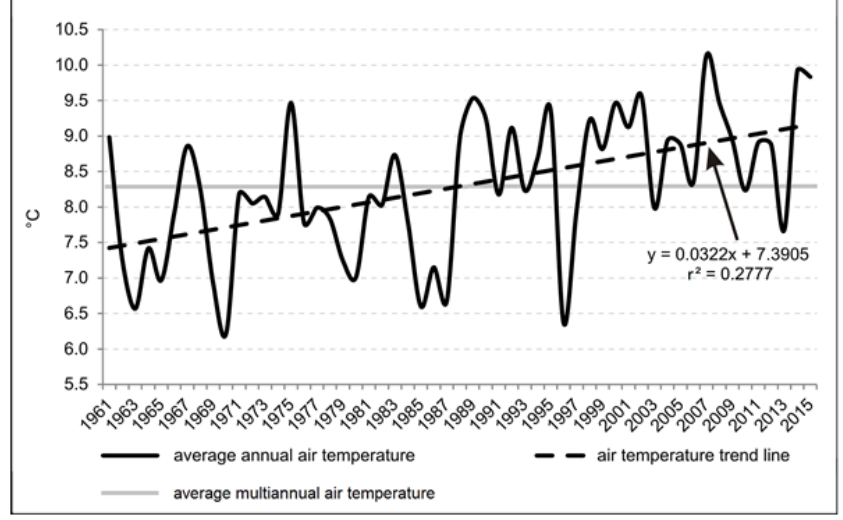

Fig. 3. Mean annual temperatures at the climatological station in Shupca in the years 1961-2015; source: own elaboration based on IMGW data

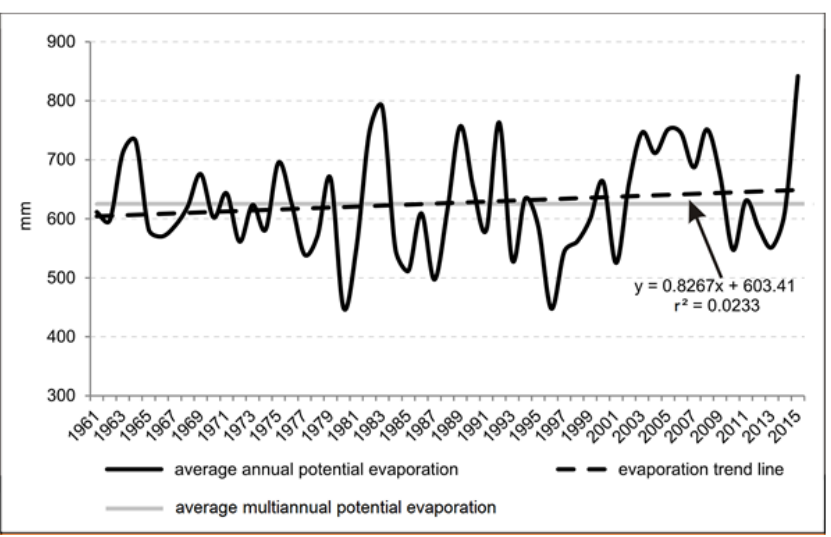

Fig. 4. Annual totals of potential evaporation for the study area in the years 1961-2015; source: own elaboration based on data from climatological stations of IMGW: Słupca, Poznań, Kołuda Wielka and Koło

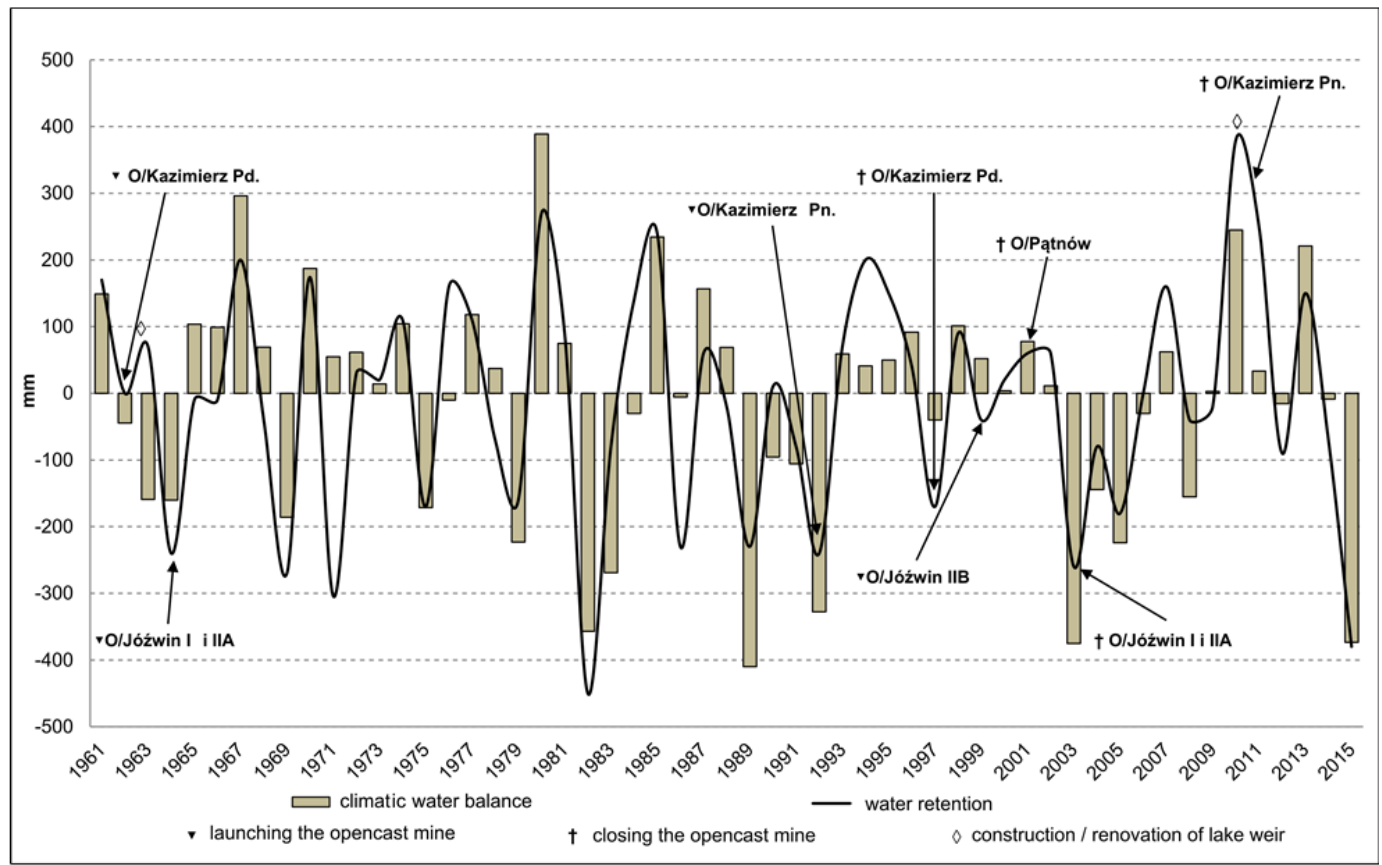

Fig. 5. Changes in retention of Lake Powidzkie on the background of climatic water balance and the dates of commissioning and closing of lignite opencast mines over the last 65 years; source: NOWAK [2018]

Tendencies of changes in precipitation and evaporation from water surface, i.e. factors determining the hydrological situation in the discussed area to the greatest extent, are presented below (Fig. 5). The climatic water balance (comparison of precipitation and evaporation) determines potential water alimentation or loss. The effect of the factor on the resources of the Lake Powidzkie can be traced on the graph presenting the resultant of annual precipitation and evaporation with changes in the lake's retention, identified as differences in states from the beginning and end of subsequent hydrological years. Periods with negative values of climatic water balance largely overlap with considerable loss of water in the lake. Years with a positive balance index correspond with an increase in water level. Very strong effect of the factor on the lake is evidenced by a high coefficient of correlation between both compared parameters, amounting to 0.78 . Strong deviations from the rule only occur in the case of individual years. This should be associated with among others the effect of the dam and development of a depression cone related to the nearby opencast brown coal mines.

\section{CATCHMENT CONDITIONS}

In addition to climatic factors, water level in lakes is determined by conditions occurring in their catchments. As mentioned above, Lake Powidzkie has a small catchment. Due to this, the possibilities of its alimentation with surface and infiltration waters are very limited, and particularly depend on the amount of precipitation in the immediate vicinity. For comparison, an example of a lake in the region (with approximate climatic conditions) but with different catchment parameters is the Lake Gopło (Fig. 1). It is fed by many tributaries, the largest one being the Notec River (draining an area of several hundred per square kilometer). The river discharges an average of $1.45 \mathrm{~m}^{3} \cdot \mathrm{s}^{-1}$ to 


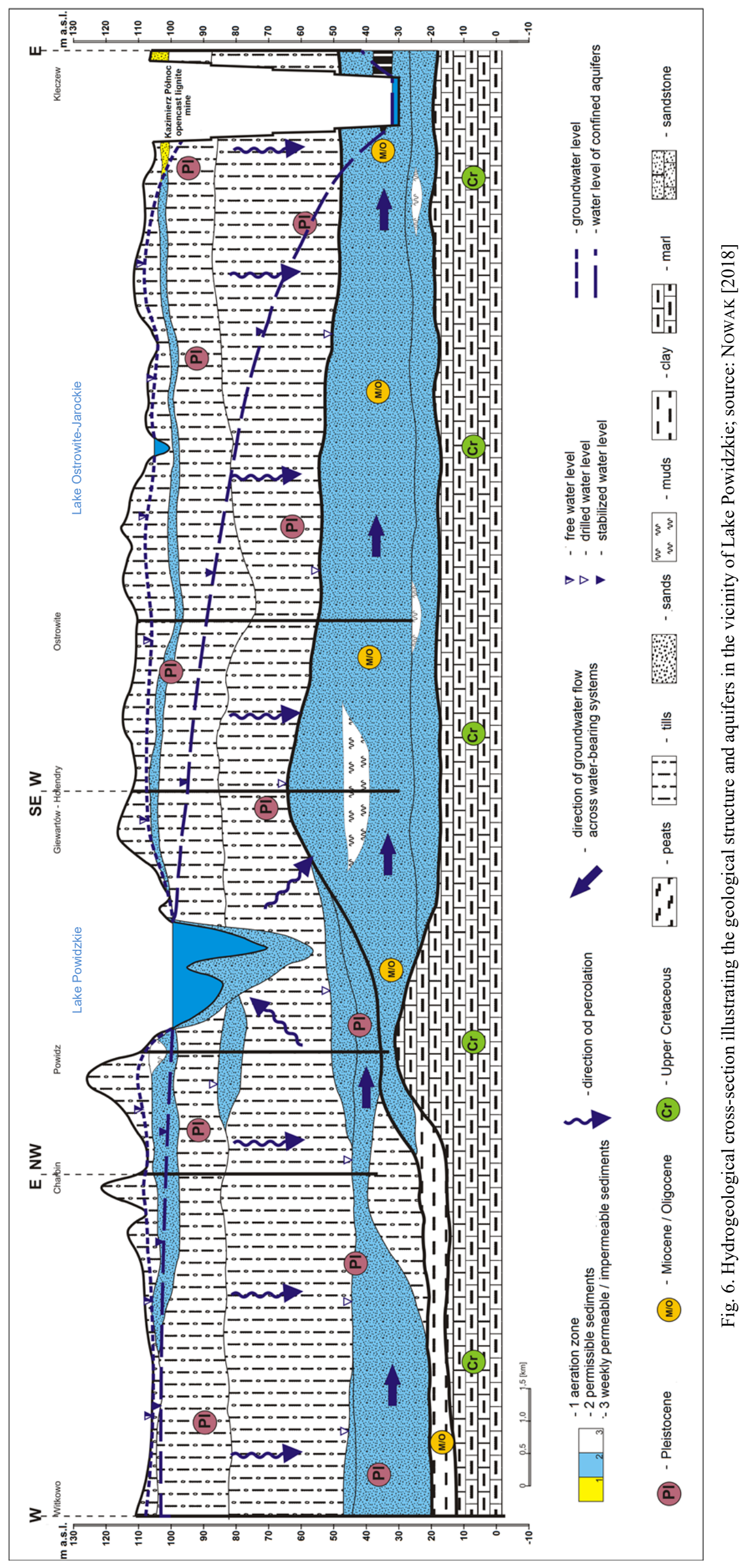


the Lake Gopło (SSQ $Q_{1981-2010}$ - data of IMGW). This allows for supplementing losses resulting from the prevalence of evaporation over precipitation. Due to the small volume of the lake, the Lake Gopło can return to its normal state after periods with no precipitation within several months. Such a situation occurred among others in 2011 [NOWAK 2012; 2016], when winter precipitation and sudden thaw caused flooding of municipalities located nearby the lake.

The Lake Powidzkie and its catchment are located in the spring area at the watershed of the Noteć and Meszna rivers and the Ślesiński Channel (Fig. 1). Because the area is elevated in comparison to the adjacent areas, water is not accumulated here. It flows rapidly towards rivers draining the area. In addition to the catchment of Lake Powidzkie, the area closely adjacent to it plays an important role in shaping the water balance. The discussed lake is surrounded by a wide belt of land elevated up to $1 \mathrm{~m}$ above the water surface, particularly in the western and northern part. It occupies an area of approximately $1.5 \mathrm{~km}^{2}$, i.e. more than $10 \%$ of the lake's surface. In the past (in the period of higher water level), the land constituted integral parts of a single water body, where intensive processes of deposition of limnic sediments occurred. The plains are particularly composed of organic sediments, and are overgrown by alder forests preferring wet habitats, rushes, or occupied by meadows. Groundwaters accumulated in the troughs remain in close hydraulic connection with the lake's waters. As a result of capillary rise, they are prone to very high evaporation, particularly on hot days with no precipitation. Due to water-thirsty plant assemblages overgrowing the areas, they are characterised by very high evapotranspiration in the vegetative period [NowAK 2018]. The losses are supplemented with waters from the lake, resulting in further impoverishment of its resources. The processes intensified after 1990, when near-shore shallow areas were overgrown by rushes, and current rushes were replaced by trees and bushes [NowAK et al. 2011]. In addition to the use of water for building their tissues, the same plants also indirectly contribute to the loss of water from the lake. Shoots of reeds and other emergent macrophytes located in the lake constitute an additional surface of evaporation for water which in conditions of strong wave action can stay on shoots even one metre above the water surface in the lake, considerably increasing the evaporation surface. Owing to surfaces obtained this way, effective evaporation from the lake overgrown by rushes is even $50 \%$ higher [NOWAK 2010] than evaporation from free water surface. In the case of lakes with non-overgrown shores, the factor does not play a substantial role, but in the case of the Lake Powidzkie, where rushes constitute a dozen percent of the entire surface area of the lake, it is of high importance, and contributes to the annual evaporation of several hundred thousand cubic meters of water more than on an analogical surface not overgrown with vegetation.

Groundwaters play an important role in the determination of the water level in the Lake Powidzkie. Due to their depth and lithology of the surrounding area, the water body dissects several aquifers (Fig. 6).

The relations between the lake and groundwater play an important role in the scope of alimentation and drainage of the lake [NowAK 2018]. The aquifer locally fed by infiltration of precipitation, and the lower inter-loam aquifer, called the Wielkopolska Buried Valley, with the alimentation zone located within the Gniezno Plateau west of the Lake Powidzkie, are of the greatest importance. In years with normal precipitation, groundwater alimentation plays an important role. In dry years, however, groundwaters of shallow aquifers constitute a low percentage of the entire alimentation due to very small direct catchments of the lakes, and land relief evidently affecting the direction of flow of groundwaters. The area is also characterised by a high contribution of uncovered arable land, exposed to direct effect of wind and solar radiation. Due to this, the land loses high amounts of accumulated water as a result of land evaporation and transpiration of cultivated plants. Groundwaters are moreover strongly exploited for irrigation purposes (I aquifer) and as drinking water (II aquifer). This additionally contributes to a reduction of their resources and therefore a decrease in their piezometric pressure and water level. The decreasing tendency of groundwater level in periods with no precipitation has a broader range, and is recorded throughout the region [NOWAK 2018; NowaK, PrzybyŁeK 2008; PrZybyŁeK, NowAK 2011]. The waters, however, are recreated relatively fast, and already after several wet years they are characterised by a state approximate to the original one (Fig. 7).

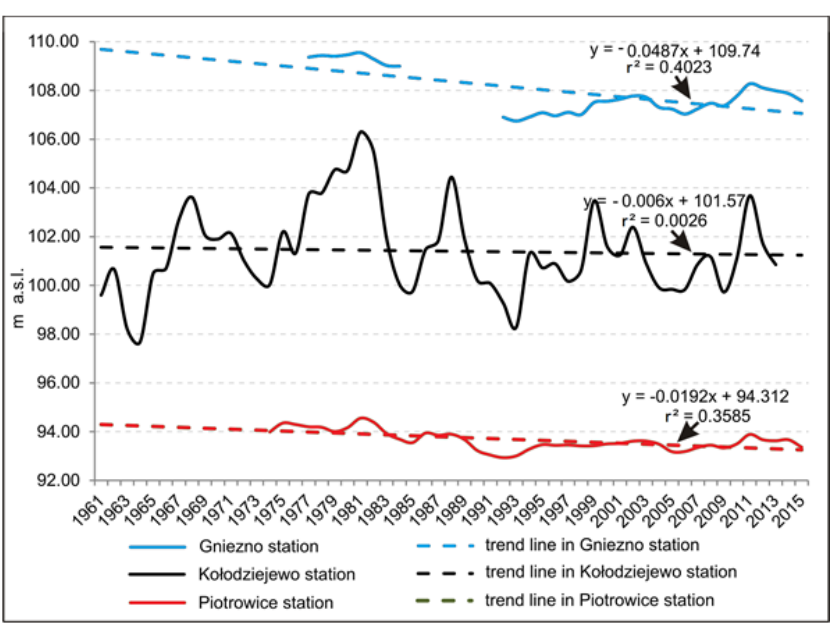

Fig. 7. Mean annual groundwater levels in the vicinity of the Gnieźnieńskie Lakeland for groundwater aquifer - Kołodziejewo and Wielkopolska Buried Valley - Piotrowice and Gniezno; source: IMWM and PGI data

A different situation occurs in the case of waters of deeper aquifers (Fig. 7), including the so-called Wielkopolska Buried Valley, constituting a regional hydrogeological structure [DĄBROWSKI 1990; PRZYBYŁEK, NOWAK 2011] remaining in close hydraulic connectivity with Lake Powidzkie [NOWAK 2018]. Waters of the aquifer are accumulated in sandy-gravel formations, usually deposited under a several tens of metres thick layer of Middle-Poland loams, effectively blocking infiltration of precipitation waters. The reconstruction of the aquifer is a process requiring many years, especially that on the eastern side of Lake Powidzkie it is connected into a single aquifer with the Miocene aquifer drained by the mine (Fig. 6). It should be 
emphasised that a decrease in the water level in the Wielkopolska Buried Valley is not only related to the drainage of opencast mines, but to many other overlapping factors, and the phenomenon itself has been observed throughout Wielkopolska already since the 1970's. It was the most intensive in the early 1990's [NowAK 2018; PRZYBYŁEK and NOWAK 2011], an exceptionally dry decade with the highest water loss in Lake Powidzkie.

\section{ANTHROPOGENIC INFLUENCES}

The fluctuations are a result of melioration and regulation measures performed since the $18^{\text {th }}$ century, leading to drying of natural places of water accumulation, systematic deforestation, and modern interference manifested in opencast exploitation of brown coal and excessive intake of groundwaters [ILNICKI 1996; 2008; ILNICKI, ORLOWSKI 2006; KANIECKI 1991; MARSZELEWSKI, RADOMSKI 2008; NOWAK 2018; NoWAK, GEZELlA-NOWAK 2012; ORŁOWSKI, ILNICKI 2007; PRZYBYŁEK, NOWAK 2011; RoTNICKA 1991]. The effect of opencast mines is the strongest in lakes located North-East of Lake Powidzkie in the catchment of the Ostrowo-Gopło Channel [NowAK 2018], covered by the depression cone of the currently exploited opencast mine Jóźwin IIB. The range of effect of the depression cone also covers the north-eastern parts of the catchment of Lake Powidzkie (Fig. 8). Due to this, it is devoid of alimentation from that area. This is suggested by among others NOWAK and MIELCAREK [2016], analysing flows in streams feeding Lake Powidzkie. As a result of stream capture of the underground catchment, due to the launch of opencast mines "Kazimierz" and "Jóźwin", the streams feeding lakes on the eastern side were devoid of their spring area. Together with the reduction of surface alimentation, and consequently the development of a depression cone around the opencast mines, the surface area from which Lake Powidzkie had been fed by infiltration waters also decreased. Water that previously flew towards lakes located in the Powidz-Ostrowo glacial channel is currently captured by the opencast mines, and then transported through the drainage network of the mines towards Struga Biskupia and Kleczewska, discharging their waters to the Ślesiński Channel. This suggests that water that had been so far retained in the lakes of the Powidz-Ostrowo glacial channel now flows towards the Warta River. In the case of Lake Powidzkie, depending on the precipitation amount and vegetative season, the area reaches from several to approximately a dozen $\%$ of total area of its catchment. It should be emphasised that the effect of opencast mines and the related mining drainage on Lake Powidzkie and other water bodies of the Powidz-Ostrowo glacial channel has been observed for at least 60 years, since the launch of opencast mine Pątnów and Kazimierz Południe. Initially, it was of no substantial importance for the lakes. However, with the front of the mines shifting towards north-west (Fig. 1), it was more and more evident. The current depression cone related to the youngest opencast mines Jóźwin IIB and Kazimierz Północ is therefore a result of mining pressure occurring in the area already since the 1960's. Unambiguous information isn't available on the range of the depression cone surrounding opencast mines of Brown Coal Mine Konin in particular decades of the $20^{\text {th }}$ century. Tracing fluctuations of Lake Powidzkie and dates of launch of particular opencast mines, however, suggests that the recorded decreases in water level in the lake largely correspond with the beginning of coal exploitation in particular pits (Fig. 5).

Another manifestation of human activity is related to intakes of groundwaters used for municipal, agricultural, and economic purposes. The majority of them in the vicinity of Lake Powidzkie are located within the level of Wielkopolska Buried Valley and Miocene aquifer, i.e. aquifers in normal conditions feeding Lake Powidzkie. Part of the waters is lost as a result of the utility processes, and the remaining wastewater is transported to wastewater treatment plants. Treated sewage in both communes, however, are discharged outside the lake's catchment - in the case of Powidz to Struga Bawół River, and in the case of Ostrowite to Struga Kleczewska River and Struga Biskupia River (Fig. 8). In combination with losses related to irrigation and municipal use of water, this leads to complete loss of resources exploited from intakes supplying water to communes located in the catchment of Lake Powidzkie. The description of groundwater intakes and water supply to the population in the area of Lake Powidzkie should emphasise that over the last twenty years, the number of recipients of the water supply network of both communes considerably increased. This is related to the developing complexes of summer houses in the region attractive in tourist terms, and the number of tourists around the lake increasing from year to year. This leads to an even 4-fold increase in water use in tourist municipalities located on Lake Powidzkie in summer, resulting in an increase in the depression cones related to groundwater intakes, and a considerable decrease in the inflow of groundwaters to the lake [NowAK 2018].

The weir built on the outflow from Lake Powidzkie was aimed at counteracting the situation. It was constructed in the 1960's, and thoroughly rebuilt in 2010. It is then that its effect on the course of water levels was evidently observed (Fig. 5), magnified by exceptionally high precipitation in the area. Inhibiting outflow caused an extraordinary increase in water level in the lake at the time, and prolonged the period of occurrence of high water levels for further several years.

\section{WATER LEVEL CHANGES}

Figure 2 presents fluctuations of mean monthly water levels in Lake Powidzkie in the years 1961-2015. The graph shows subsequent periods of occurrence of high and low water levels, overlapping with seasonal fluctuations. In the analysed multiannual period, the highest water levels were recorded in 1968, 1962, and 1981, and the lowest in 1992, 1993, and 2006 (Fig. 9). The multiannual amplitude of water level fluctuations in the lake amounted to $1.2 \mathrm{~m}$. Considering the obvious response of the discussed lake to natural climatic fluctuations, a broader image of water level fluctuations referring to their directions looks unfavourable. A trend of decreasing water levels in the lake is evi- 


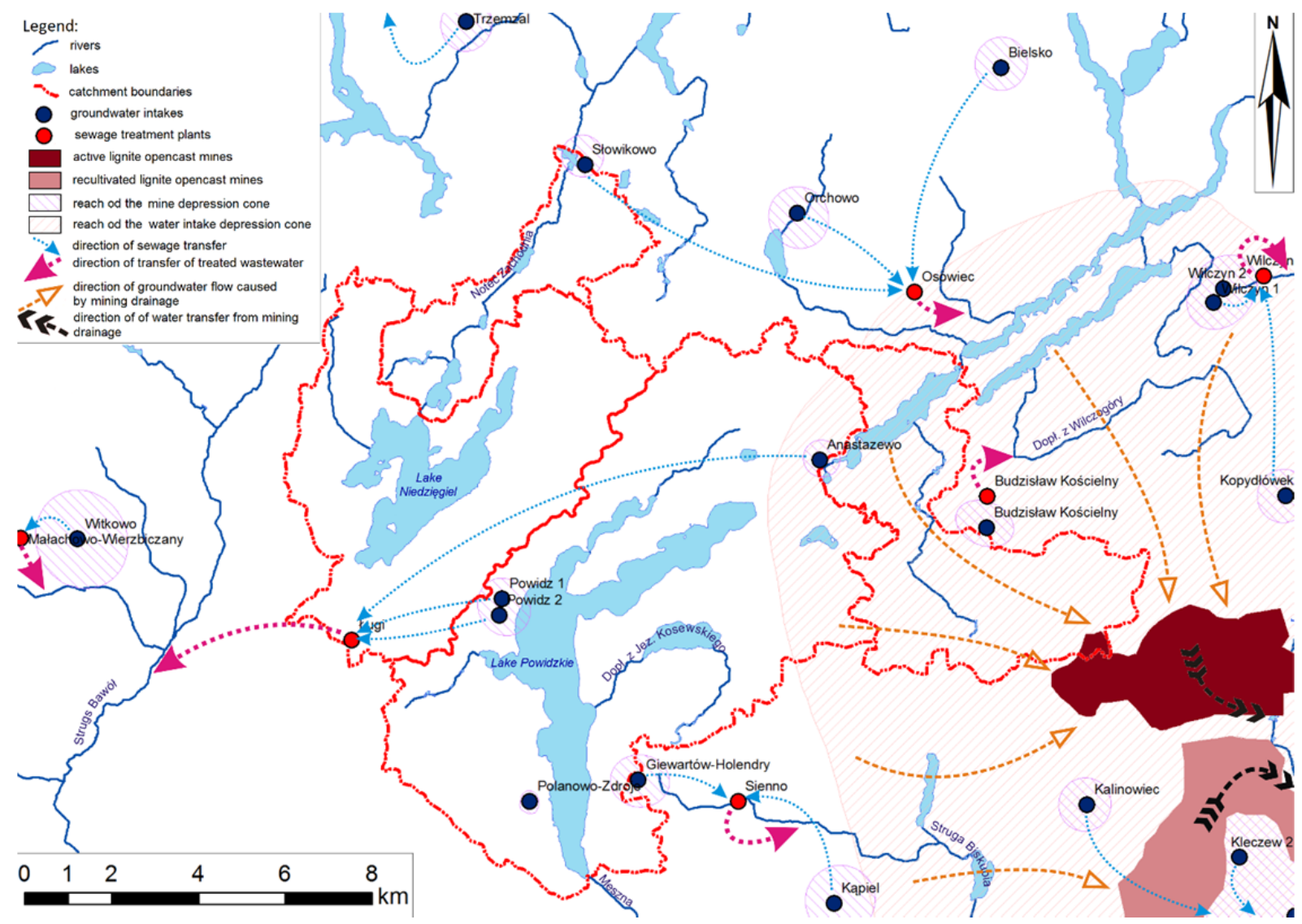

Fig. 8. Water and sewage management in the area of Lake Powidzkie; source: NowAK 2018

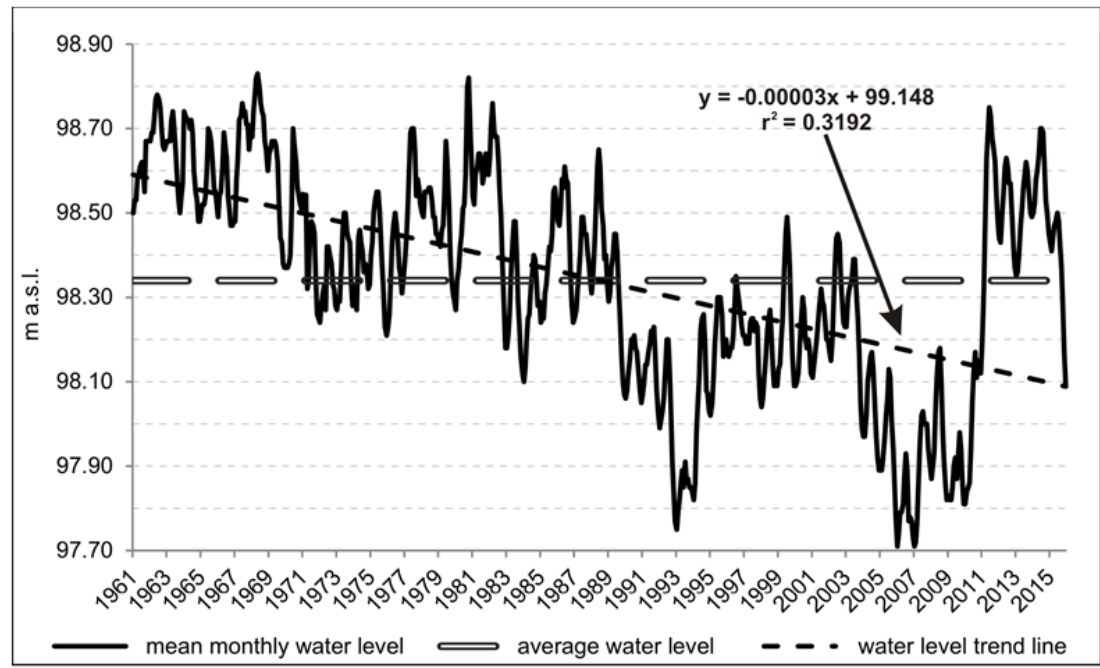

Fig. 9. Mean monthly water levels in Lake Powidzkie in the years 1961-2015; source: based on the NOWAK and PTAK [2018], modified

dent, amounting to $9 \mathrm{~cm} \cdot \mathrm{decade}^{-1}$. The highest water level observed in the lake occurred in the 1960's, and decreased with every decade until the first decade of the $21^{\text {st }}$ century (Fig. 9). Only after 2010 the process was temporarily inhibited as a result of both natural factors (high precipitation) and human activity (hydrotechnical infrastructure on the outflow from the lake) [NOWAK, PTAK 2018]. Studies concerning water level fluctuations in Polish lakes are difficult to refer to such a situation [KOWALIK et al. 2008; PTAK et al. 2017; VOLCHAK et al. 2017; WRZESIŃSKI et al.
2018], because in the case of the analysed lake anthropogenic activities were of key importance [NOWAK 2018; NOWAK, PTAK 2018], and such measures were not implemented in other cases.

The course of water level fluctuations in Lake Powidzkie confirms the statement on the complexity of the process in reference to the water level dynamics. The observed considerable decrease in water level over the last several decades is a resultant of the combination of the unfavourable climatic-physiographic conditions and inten- 
sive human activity in the area. The issue of co-occurrence of both factors has been discussed in the literature on the subject many times. BONACCI et al. [2015] describe the case of Lake Dojran on the border of Macedonia and Greece, where a decrease in water level in the years 19882002 amounted to $6 \mathrm{~m}$, and the answer to the question about the main cause of the process is difficult. WANG et al. [2016] describe the case of Lake Taihu (China), where water levels were dependent on precipitation, and after 2000 on the direction of water flow from Jangcy to the lake. YIN et al. [2013] describing other lakes in China (Hongze) emphasise that the maximum water level until the 1950's particularly depended on natural factors, and after that period the main role was played by anthropogenic activity (particularly hydrotechnical). YILDIRIM et al. [2011] analysing natural and anthropogenic elements responsible for a decrease in water level in Lakes Akşehir and Eber (Turkey) determined that it was particularly caused by the latter (increase in water use for agricultural and household purposes, construction of dams). ASSANI et al. [2014] analysed water level fluctuations in Lake Ontario in the years 1918-2010, and concluded that changes in the tendency and stationary character of water levels resulted from both climatic (draughts from the 1930's) and anthropogenic factors (construction of a system of canals and dams in the 1950's).

A decrease in the water level in Lake Powidzkie as well as other lakes of the Powidzki Landscape Park is a problem that has been attracting interest for many years, both among local community and among scientists. Studies on the subject provide various arguments concerning the role of natural and anthropogenic conditions responsible for the current situation [ILNICKI 2008; STACHOWSKI et al. 2016]. Next to shallowing, a decrease in water level in lakes [CHOIŃSKI et al. 2014] constitutes the key element of their decline.

In the case of the analysed lake, in spite of the complex conditions responsible for a decrease in water level described in the paper, the dominant role of man should be emphasised. This is confirmed by earlier observations by PRZYBYŁEK and NOWAK [2011]. In reference to the eastern and central part of the Gnieźnieńskie Lakeland they determined an important role of climatic factors responsible for water level decrease. In the vicinity of the Ostrowo-Gopło Channel, however, they also identified mining meliorations as the cause of level decrease in lake waters and groundwaters. The meliorations lead to the development of a depression cone on the eastern side of the sequence of lakes. It considerably contributed to the limitation of the possibilities of groundwater alimentation of the lakes. KUNZ et al. [2010] performed the analysis of changes in the surface area of Lake Ostrowskie. They determined that the changes were caused by melioration works, and in the recent period by mining meliorations. As a consequence, the lake was divided into two independent basins. The role of man was described by WRZESIŃSKI and PTAK [2016] based on a different example. Their analysis covered the course of water levels in Lake Powidzkie and Lednica Lake located at a distance of approximately $47 \mathrm{~km}$. According to the division into climatic regions by Woś [2010], both lakes are located in the same region (Fig. 1) and are subject to the same climatic conditions, but their response regarding water level fluctuations is different. The course of mean annual water levels in the period 1976-2010 suggests that Lake Lednica was characterised by an increasing tendency, and a decrease in water level in Lake Powidzkie was observed at a rate of $0.15 \mathrm{~m} \cdot$ decade $^{-1}$. In the same paper, water level fluctuations of a total of 32 lakes from the area of lakelands of north Poland were analysed. In none of the analysed cases a decrease in water level was as high as in Lake Powidzkie. Similar conclusions were drawn by KOWALIK et al. [2008], analysing the response of lakes from the catchment of the Oder River to extreme changes in their alimentation.

\section{CONCLUSIONS}

The hydrological situation of Lake Powidzkie is shaped by many factors, and each time it should be considered in such an approach. Several decades of observations show that the multiannual amplitude of water level fluctuations in the lake was $1.2 \mathrm{~m}$, and the water level decreased by an average of $9.2 \mathrm{~cm} \cdot \mathrm{dec}^{-1}$. Although their phases can be distinguished over several decades (as a response to climatic fluctuations), the general character of changes in evidently decreasing. It can be considered as the effect of drying of the entire discussed catchment, resulting in the recorded decrease in the level of surface, near-surface waters, or groundwaters, or complete disappearance of streams. The unfavourable climatic situation (in accordance with the presented data, and particularly an increase in air temperature) overlapped with meliorations leading to a situation where even high precipitation is not able to balance the retention capacity of the catchment. Human activity caused a disturbance in the current system of water circulation throughout the region. The need for counteracting the situation is obvious, as confirmed by the weir built on the outflow from Lake Powidzkie. Unfortunately, such point-based actions (unlike large-area and local meliorations) permitted retaining excess water in the lake only in conditions of very high precipitation.

The problem of water level decrease in Lake Powidzkie as well as the entire region is complex in several terms. One of the aspects is the degradation of its high environmental values. Except for the purely environmental aspect, the fact can also result in measurable economic effects related to a reduction of the tourist potential, or possibility of use of water for agricultural purposes. On the other hand, with regard to the economic aspect, the conducted mining activity constitutes and has constituted the main factor of development of the region.

\section{ACKNOWLEDGEMENTS}

This work was supported by the National Science Center research project for young scientists entering education, without doctoral degree - PRELUDIUM entitled "Lakes in circulation and drainage of groundwater in the area of the last glacial period in natural conditions and conditions of hydrodynamic pressure" (UMO2011/03/N/ST10/05014), implemented in 2012-2015. 


\section{REFERENCES}

Assani A.A., LANDRy R., Biron S., Frenette J.-J. 2014. Analysis of the interannual variability of annual daily extreme water levels in the St Lawrence River and Lake Ontario from 1918 to 2010. Hydrological Processes. Vol. 28. Iss. 13 p. 4011-4022. DOI 10.1002/hyp.9941.

Bank Hydro undated. Dane hydrogeologiczne Państwowej Służby Hydrogeologicznej [Hydrogeological data of Polish State Hydrogeological Survey] [online]. Warszawa. Centralny Bank Danych Hydrogeologicznych. [Access 31.10.2015]. Available at: https://www.pgi.gov.pl/psh/danehydrogeologiczne-psh/947-bazy-danych-hydrogeologiczne/ 9057-bankhydro.html

Bonacci O., Popovska C., Geshovska V. 2015. Analysis of transboundary Dojran Lake mean annual water level changes. Environmental Earth Sciences. Vol. 73. Iss. 7 p. 3177-3185. DOI 10.1007/s12665-014-3618-6.

BYCZKOWSKi A. 1999. Hydrologia [Hydrology]. T. 2. Warszawa. Wydaw. SGGW. ISBN 83-7244-069-7 pp. 356.

Choiński A., PtaK M., StrzelczaK A. 2014. Present-day evolution of coastal lakes based on the example of Jamno and Bukowo (the Southern Baltic coast). Oceanological and Hydrobiological Studies. Vol. 43. Iss. 2 p. 178-184. DOI 10.2478/ s13545-014-0131-1.

ChOIŃSKi A., ŁAWniczak A., PTAK M. 2016. Changes in water resources of Polish lakes as influenced by natural and anthropogenic factors. Polish Journal of Environmental Studies. Vol. 25 p. 1883-1890. DOI 10.15244/pjoes/62906.

Chomicz K. 1976. Opady rzeczywiste w Polsce (1931-1960) [Actual rainfall in Poland (1931-1960)]. Przegląd Geofizyczny. R. 21 (29). Z. 1 p. 19-25.

DĄBROWSKI S. 1990. Hydrogeologia i warunki ochrony wód podziemnych Wielkopolskiej Doliny Kopalnej [Hydrogeology and conditions for the protection of groundwater in the Wielkopolska Buried Valley]. Warszawa. Wydaw. SGGW pp. 56.

ILNICKI P. 1996. Wpływ drenażu odkrywek węgla brunatnego na walory rekreacyjne Pojezierza Gnieźnieńskiego [The impact of lignite opencast drainage on the recreational values of the Gnieźnieńskie Lakeland]. Aura. Nr 11 p. 10-12.

ILNICKI P. 2008. Ratowanie jezior Powidzkiego Parku Krajobrazowego [Rescue of the lakes of the Powidzki Landscape Park]. Biuletyn Parków Krajobrazowych Wielkopolski. Nr 15 p. 48-65.

ILNICKI P., ORŁOWSKI W. 2006. Ocena oddziaływania odwodnienia odkrywek w rejonie Kleczewa prowadzonych przez Kopalnię Węgla Brunatnego „Konin” S.A. w Kleczewie, na poziomy wody $\mathrm{w}$ jeziorach położonych przy wododziale rzeki Noteci i rzeki Warty [Evaluation of the impact of lignite opencast drainage in the Kleczew region conducted by the Brown Coal Mine "Konin" S.A. in Kleczew on water levels in lakes located near the Noteć River and Warta River watershed]. Poznań. Polskie Towarzystwo Rybackie pp. 201.

JAŃCZAK J., CHOIŃSKI A. 1988. Wahania poziomów wody jezior w latach 1956-1985. W: Naturalne i antropogeniczne przemiany jezior i mokradeł $\mathrm{w}$ Polsce [Water level fluctuations in selected lakes in Poland in the years 1956-1985. In: Natural and anthropogenic transformations of lakes and wetlands in Poland]. Ed. Z. Churski. Torun. UMK p. 9-88.

JAWORSKI J. 2004. Parowanie w cyklu hydrologicznym zlewni rzecznych [Evaporation in the hydrological cycle of river catchments]. Warszawa. PTGeof. ISBN 978-83-916-0311-6 pp. 422.

JURAK D. 1986. Parowanie z powierzchni wody. W: Atlas hydrologiczny Polski [Evaporation from the water surface. In: Hydrological atlas of Poland]. T. 1. Ed. J. Stachỳ. Warszawa. Wydaw. Geologiczne p. 43-47.
KaCZOrOwSKa Z. 1962. Opady w Polsce w przekroju wieloletnim [Precipitation in Poland in long-period Averages]. IG PAN. Prace Geograficzne. Nr 33 pp. 112.

KANIECKI A. 1991. Zmiany stosunków wodnych w rejonie Konina związane $\mathrm{z}$ działalnością kopalnictwa odkrywkowego. W: Przemiany środowiska geograficznego obszaru KoninTurek [Changes in the water conditions of the Konin region generated by opencast mining. In: Changes in the natural environment of the Konin-Turk area]. Ed. W. Stankowski. Poznań. Wydaw. Nauk. UAM p. 137-151.

KANIECKI A. 1997. Wpływ XIX-wiecznych melioracji na zmiany poziomu wód. W: Wpływ antropopresji na jeziora [Influence of $19^{\text {th }}$ century reclamations on the changes in water level. In: Impact of anhropopressure on lakes]. Ed. A. Choiński. Poznań. Wydaw. Nauk. UAM p. 67-71.

KANIECKI A. 2007. Przemiany stosunków wodnych na obszarze Niziny Wielkopolskiej do końca XVIII wieku związane z antropopresją. W: Obieg wody w środowisku naturalnym i przekształconym [Changes of water relations in the area of Wielkopolska Lowland until the end of the $18^{\text {th }}$ century connected with anthropopressure. In: Circulation of water in a natural and transformed environment]. Ed. Z. Michalczyk. Lublin. Wydaw. UMCS p. 304-318.

KĘDZIORA A. 2008a. Podstawy agrometeorologii [Basics of agrometeorology]. Poznań. PWRiL. ISBN 978-83-090-1040-1 pp. 380.

KĘDZIORA A. 2008b. Bilans wodny krajobrazu konińskich kopalni odkrywkowych w zmieniających się warunkach klimatycznych [Water balance of Konin strip mine landscape in changing climatic conditions]. Roczniki Gleboznawcze. T. 59. Nr. 2 p. 104-118.

KęDZIORA A. 2011. Warunki klimatyczne i bilans wodny Pojezierza Kujawskiego [Climatic conditions and water balance of the Kujawy Lakeland]. Roczniki Gleboznawcze. T. 62. Nr 2 p. 189-203.

KondRaCKi J. 2009. Geografia regionalna Polski [Regional geography of Poland]. Warszawa. Wydaw. Nauk. PWN. ISBN 978-83-01-16022-7 pp. 441.

KowALCZYK S., UJDA K. 1987. Pomiary porównawcze opadów atmosferycznych [Comparative measurements of precipitation]. Materiały Badawcze IMGW. Seria Meteorologia. Nr 14 p. 3-48.

Kowalik A., GrZeŚKowiaK A., NowaK B. 2008. Reakcja jezior na ekstremalne zmiany ich zasilania [Lake's reaction to extreme changes in their supply]. Wiadomości Meteorologii, Hydrologii, Gospodarki Wodnej. T. 52. Z. 3-4 p. 49-68.

Kunz M., SKOwron R., SKOwrońSKi S. 2010. Morphometry changes of Lake Ostrowskie (the Gniezno Lakeland) on the basis of cartographic, remote sensing and geodetic surveying. Limnological Review. Vol. 10. Iss. 2 p. 77-85. DOI 10.2478/v10194-011-0009-1.

MARSZELEWSKI W., RADOMSKI B. 2008. Quantitative degradation of water resources of the lakes in the eastern part of the Gniezno Lakeland. In: Anthropogenic and natural transformations of lakes. Vol. 2. Eds. E. Bajkiewicz-Grabowska, D. Borowiak. Gdańsk. Polskie Towarzystwo Limnologiczne p. 119-122.

MiKULSKI Z. 2000. Rozwój badań bilansu wodnego i próba jego oceny w XX wieku w Polsce [Development of water balance research and an attempt to evaluate it in the $20^{\text {th }}$ century in Poland]. Wiadomości IMGW. Vol. 23 (44). Nr 2 p. 69-75.

Minea G., Adler M.J., Patru G. 2016. A hydrometric and hydrological approach test at microscale. Procedia Environmental Sciences. Vol. 32 p. 275-280.

MolgA M. 1951. O wpływie wysokości umieszczenia deszczomierza na wielkość opadów atmosferycznych [On the influence of the height of the rain gauge placement on the amount 
of atmospheric precipitation]. Gazeta Obserwatora PIHM. Nr 10 p. $1-4$.

NowAK B. 2010. Effect of rushes on evaporation rate in water reservoirs in the example of Powidzkie Lake. Limnological Review. Vol. 10. Iss. 1 p. 37-41.

NowAK B. 2012. The causes of Gopło Lake flood in winter 2011. In: Natural and anthropogenic transformations of lakes. Conference materials of International Limnological Conference. Eds. A. Grześkowiak, B. Nowak. 19-21.09.2012 Łagów Lubuski. Poznań. IMGW-PIB p. 69-70.

NowAK B. 2016. Wyznaczanie linii brzegowej jezior - zapisy w ustawie a uwarunkowania przyrodnicze i gospodarcze [Determining shoreline of lakes in Poland - provisions of the legal act versus natural and economic considerations]. Gospodarka Wodna. Nr 10 (814) p. 345-350.

NowAK B. 2018. Rola jezior w kształtowaniu zasilania i drenażu wód podziemnych na Pojezierzu Gnieźnieńskim w warunkach naturalnych i antropopresji hydrodynamicznej [The role of lakes in drainage and recharge of groundwater in Gnieźnieńskie Lakeland area in natural conditions and conditions of hydrodynamic anthropopressure]. PhD Thesis. Poznań. Instytut Geologii UAM pp. 198.

NowAK B., BrodzińSKA B., Gezella-NowAK I. 2011. Natural and economic factors of shrinkage of lakes of the Wielkopolska Lakeland. Limnological Review. Vol. 11. Iss. 3 p. 123-132.

NowaK B., Gezella-NowaK I. 2012. Causes of severe lowflows events of Powidzkie Lake (Gniezno Lakeland). In: Natural and anthropogenic transformations of lakes. Conference materials of International Limnological Conference. Eds. A. Grześkowiak, B. Nowak. 19-21.09.2012 Łagów Lubuski. Poznań. IMGW-PIB p. 71-72.

NowaK B., MielcareK M. 2016. Water resources of Powidzkie Lake and its catchment. In: Lakes, Reservoirs and Ponds Impacts - Threats - Conservation. Books of abstracts International Conference. Eds. P. Klimaszyk, W. Marszelewski, P. Rzymski. 31.05-03.06.2016 Iława (Poland). Toruń. Polskie Towarzystwo Limnologiczne p. 163-168.

NowaK B., PrzybyŁeK J. 2008. Groundwater level oscillation in the Poznańskie Lake District during the last three decades and its impact on lakes on the example of Góreckie Lake. In: Anthropogenic and natural transformations of lakes. Vol. 2. Eds. E. Bajkiewicz-Grabowska, D. Borowiak. Gdańsk. Polskie Towarzystwo Limnologiczne p. 135-137.

NowAK B., PTAK M. 2018. Effect of a water dam on Lake Powidzkie and its vicinity. Bulletin of Geography. Physical Geography Series. Vol. 15 p. 5-13.

ORŁOWSKI W., ILNICKI P. 2007. Problemy gospodarowania wodą w otoczeniu Kopalni Węgla Brunatnego Konin [Problems of water management in the surroundings of the Brown Coal Mine Konin]. Gospodarka Wodna. Nr 9 p. 383-386.

PrzybyŁeK J., NowaK B. 2011. Wpływ niżówek hydrogeologicznych i odwodnień górniczych na systemy wodonośne Pojezierza Gnieźnieńskiego [Impact of hydrogeological low flows and groundwater drainage by lignite open cast mine on aquifer systems of Gniezno Lakeland]. Biuletyn PIG. Nr 445 p. 513-527.

Ptak M., Choiński A., Strzelczak A., TArgosz A. 2013. Disappearance of Lake Jelenino since the end of the XVIII century as an effect of anthropogenic transformations of the natural environment. Polish Journal of Environmental Studies. Vol. 22. Iss. 1 p. $191-196$

PTAK M., WRZESIŃSKI D., CHOIŃSKI A. 2017. Long-term changes in the hydrological regime of high mountain lake Morskie Oko (Tatra Mountains, Central Europe). Journal of Hydrology and Hydromechanics. Vol. 65 p. 146-153.

RotNICKA J. 1991. Zmiany w zakresie bilansu wód powierzchniowych i podziemnych w obszarach eksploatacji węgla bru- natnego regionu Konina (odkrywki Pątnów, Jóźwin, Kazimierz). W: Przemiany środowiska geograficznego obszaru Konin-Turek [Changes in the surface and ground water balance in the Konin brown-coal mining area. In: Changes in the natural environment of the Konin-Turk area]. Ed. W. Stankowski. Poznań. Wydaw. Nauk. UAM p. 153-163.

Rösler A., Bielawny K., Chmal M., Chmal T., Staszkiewicz S., Szymanowska K. 2007. Analiza zmian składowych bilansu wodnego jezior na przykładzie jeziora Sława (19762005) [Analysis of changes in the components of lake water balance on the example of Sława Lake (1976-2005)]. Report on the research task of DS. - H 1.6b. Poznań. IMGW pp. 24.

RöSLER A., ChMAL M. 2010. Korekta opadu w bilansie wodnym. W: Dynamika procesów przyrodniczych w zlewni Drawy i Drawieńskim Parku Narodowym [Correction of precipitation in the water balance. In: The dynamics of natural processes in the Drawa River catchment and Drawieński National Park. Eds. A. Grześkowiak, B. Nowak. Poznań. IMGW-PIB - Polskie Towarzystwo Geofizyczne p. 127-132.

Rösler A., Chmal M., Chmal T. 2013. Parowanie z powierzchni wody - porównanie wzorów z pomiarami. W: Naturalne i antropogeniczne przemiany jezior [Evaporation from the water surface - a comparison of patterns with measurements. In: Natural and anthropogenic transformations of lakes]. Materiały konferencyjne XVII Ogólnopolskiej Konferencji Limnologicznej. Ed. J. Dunalska. 24-27.09.2013 Olsztyn-Ryn. Olsztyn. UWM p. 68-70.

Stachowski P., Oliskiewicz-Krzywicka A., KuPIEC J.M. 2016. Naturalne uwarunkowania stanu wód jezior w rejonie Kopalni Węgla Brunatnego „Konin” [The natural characteristics of the state of the water in lakes in the area of Open Mine Quarry "Konin"]. Rocznik Ochrona Środowiska. T. 18. Nr 1 p. $642-669$.

VolchaK A., Choiński A., KiRviel I., PARFomuK S. 2017. Spectral analysis of water level fluctuations in Belarusian and Polish lakes. Bulletin of Geography. Physical Geography Series. Vol. 12 p. 51-58.

Wang L., Hu Q. Hu Y., Wang Y., Lin H. 2016. Changes and cause analysis of water level characteristic factors in Taihu Lake during period from 1954 to 2013. Journal of Hohai University. Vol. 44 (1) p. 13-19.

Woś A. 2010. Klimat Polski w drugiej połowie XX wieku [The climate of Poland in the second half of the $\mathrm{XX}^{\text {th }}$ century]. Poznań. Wydaw. Nauk. UAM. ISBN 978-83-232-2180-7 pp. 489.

WrZesiński D., Ptak M. 2016. Water level changes in Polish lakes during 1976-2010. Journal of Geographical Sciences. Vol. 26. Iss. 1 p. 83-101. DOI 10.1007/s11442-016-1256-5.

WrZESIŃSKi D., PTAK M. 2017. An investigation of water level fluctuations in Polish lakes in various phases of the winter North Atlantic Oscillation. Geology, Geophysics and Environment. Vol. 43. No. 2 p. 151-163. DOI 10.7494/geol.2017. 43.2.151.

Wrzesiński D., Ptak M., Plewa K. 2018. Effect of the North Atlantic Oscillation on water level fluctuations in lakes of northern Poland. Geographia Polonica. Vol. 91. Iss. 2 p. 243259. DOI 10.7163/GPol.0119.

YildiRIM U., ERDOǦAN S., UYSAL M. 2011. Changes in the coastline and water level of the Akşehir and Eber Lakes between 1975 and 2009. Water Resources Management. Vol. 25. Iss. 3 p. 941-962. DOI 10.1007/s11269-010-9735-4.

YIN Y., Chen Y., Yu S., Xu W., Wang W., Xu Y. 2013. Maximum water level of Hongze Lake and its relationship with natural changes and human activities from 1736 to 2005 . Quaternary International. Vol. 304 p. 85-94. DOI 10.1016/ j.quaint.2012.12.042. 


\section{Bogumil M. NOWAK, Mariusz PTAK}

Naturalne i antropogeniczne uwarunkowania wahań poziomu wody w jeziorach na przykładzie Jeziora Powidzkiego, środkowo-zachodnia Polska

\section{STRESZCZENIE}

W artykule dokonano analizy zmian poziomu wody Jeziora Powidzkiego w latach 1961-2015. Z przeprowadzonych badań wynika, że w powyższym wieloleciu nastąpił znaczny spadek średnich stanów wody, średnio o $9 \mathrm{~cm} \cdot d e k{ }^{-1}$. Sytuacja taka spowodowana jest czynnikami naturalnymi i antropogenicznymi, które współoddziałują na kształtowanie się stosunków wodnych na badanym obszarze. Do pierwszych należy zaliczyć ilość i rozkład opadów, wzrost temperatury powietrza oraz niekorzystne relacje jezioro-zlewnia. Drugie to przede wszystkim długotrwałe przeobrażenia środowiska przyrodniczego w tym regionie, które obecnie utożsamiane są z odwodnieniami, towarzyszącymi pobliskim odkrywkom węgla brunatnego oraz eksploatacji wód podziemnych na potrzeby komunalne. Wykazano, że niedobory wody, powstające podczas okresów suchych, nie są rekompensowane na badanym obszarze w latach wilgotnych, co z kolei związane jest głównie z regionalnym obniżeniem poziomu wód podziemnych, z którymi Jezioro Powidzkie pozostaje w ścisłym kontakcie. Przeciwdziałanie niekorzystnej sytuacji hydrologicznej stanowi zabudowa hydrotechniczna, która poprzez piętrzenie jeziora częściowo ogranicza ubytek wody z akwenu.

Słowa kluczowe: antropopresja środowiskowa, Jezioro Powidzkie, warunki klimatyczne, zasoby wodne, zmiany poziomu wody 